\title{
Implications of the Genetics of Root Structure in Melon Breeding
}

\author{
Ana Fita, Belén Picó, and Fernando Nuez ${ }^{1}$ \\ Center for the Conservation and Breeding of Agricultural Biodiversity (COMAV), Camino de Vera, 14, \\ 46022, Valencia, Spain
}

\begin{abstract}
AdDitional INDEX WORDs. vine decline, root architecture, heritabilities, Cucumis melo ssp. agrestis, soil stress
Abstract. Roots are critical for plants to withstand environmental abiotic and biotic stresses. Wild taxa are often used as source of variation for improving root systems, as they are adapted to more stressful soil environments than their cultivated relatives. We studied the genetics of traits related to root biomass, root length, and root architecture (considering the primary/secondary and the tertiary root levels) in melon (Cucumis melo L.) in a 2-year assay by examining the root systems of mature plants in $91 \mathrm{~F}_{3}$ families derived from the cross between a wild accession, Pat 81 [C. melo ssp. agrestis (Naud) Pangalo], and a cultivated accession, 'Piel de sapo' (C. melo ssp. melo L.). Despite the difficulties of working with adult plants, we found that Pat 81 and 'Piel de sapo' differ greatly in their mature root systems, which is in concordance with the results previously obtained with young roots. Pat 81 developed roots with less biomass than 'Piel de sapo', but this wild accession had more favorable root length and architectural traits: a higher density of framework roots, more uniformly distributed along the soil profile, longer laterals with a higher density of branches, and a higher number of root orders. This root structure is linked to a deeper rooting ability and to the capacity of exploiting a larger soil volume. The genetic analysis indicated that length and architectural traits are more stable than biomass traits, both between years and between developmental stages. Moderate to low broad- and narrow-sense heritabilites were found for root length and architectural traits, with most of the observed variation due to additive effects. Our results suggest that Pat 81 could be used as donor of valuable genes for increasing root length and improving the root architecture of cultivated melons, producing melons potentially more tolerant to soil stresses. The lack of phenotypic and genetic correlations between length and architectural parameters and root biomass suggest that root structure can be successfully improved without increasing carbon expenditures.
\end{abstract}

Root systems in plants serve many important tasks, which are mainly associated with water and nutrient absorption, anchorage of the plant, the production of fitoregulators, and interactions with soil biota. Alarge and healthy root system provides benefits to the plant, such as enhanced water- and nutrient-absorbing capacity, greater exposure to beneficial soil microorganisms, and, potentially, a high tolerance to stressful soil environments.

Breeding crops for efficient root systems is not an easy task. First, it is necessary to define which characteristics determine an "ideal" root in meeting our breeding objectives. This requires extensive knowledge of root performance in soils. In addition, extracting roots from the soil is tedious and time-consuming, and root complexity as well as their interaction with the soil makes them difficult to study. These difficulties condition the age of the plants analyzed and the root traits evaluated. The use of seedlings or young plants facilitates root analysis, but in these cases it is essential to demonstrate that there is a reasonable analogy between seedling root characteristics and those found in adult plants (Clarke and McCaig, 1993). Regarding root evaluation, a general tendency in root research has been the study of easily measured traits related to root biomass. However, root studies based on these traits have been only marginally successful and several authors have suggested that future root research should focus on other root traits, such as those related to root architecture. Literature on roots of crop species indicates very few instances of

Received for publication 11 Oct. 2005. Accepted for publication 7 Feb. 2006. We would like to thank Eva Martinez for her technical assistance. This study was supported by the project AGL2003-04817/AGR from the Spanish Ministry of Science and Technology. We would like to thank Dr. Jonathan Lynch (Penn State, Dept. of Horticulture) for his critical comments on the manuscript.

'To whom reprint request should be addressed. E-mail address: fnuez@btc. upv.es the evaluation of root architecture (Johnson et al., 2000; Lynch, 1995; Nicola, 1998; Wells and Eissenstat, 2003).

Another crucial step in improving root systems is the identification of genetic variation for favorable root traits and the determination of its genetic control (Leskovar and Stoffella, 1995). Wild taxa can be a useful source of variation for breeding root systems, since their roots usually exploit unpredictable and stressful soil environments (Chapin et al., 1989; Jackson and Koch, 1997; Siddique et al., 1990). An example of this can be found within $C$. melo. This is a diploid species $(2 \mathrm{n}=24)$ andromonoecious and facultative self-pollinating with a variable degree of outcrossing in natural conditions. It is divided into two subspecies: melo and agrestis (Jeffrey, 1980). Most cultivated melons, included in the subspecies melo, are adapted to the low environmental stress regime typical of intensive agriculture, and tend to develop a shallow root system that mainly grows in the upper layers of the soil. On the other hand, the subspecies agrestis includes wild, semi-wild, and weedy germplasm (exotic African, Indian, and Oriental melons), which are better adapted to lowinput environments. These accessions can be used as the donors of valuable genes for breeding cultivated melons, as both taxa are fully interfertile (Mliki et al., 2001; Monforte et al., 2003).

During a breeding program aimed at developing melon cultivars resistant to melon vine decline (a soilborne disease caused by Monosporascus cannonballus Pollack et Uecker), the Asiatic accession C. melo ssp. agrestis Pat 81 was selected (Esteva and Nuez, 1994; Iglesias and Nuez, 1998; Iglesias et al., 1999). Pat 81 displayed high resistance to vine decline under high inoculum pressure conditions. Two different mechanisms are involved in this resistance. First, Pat 81 shows partial resistance to pathogeninduced root lesions. Second, its extensive lateral root system, deeply penetrating in the soil, contributes to its tolerance to vine decline(Iglesias et al., 2000a, 2000b). In addition, Pat 81 explores a 
higher soil volume in comparison with susceptible melon cultivars in pathogen-free soils. Such differences in root systems have not been reported within the subspecies melo (Crosby, 2000; Crosby et al., 2000). Thus, Pat 81 could be considered a valuable model for the investigation of the genetics of root architecture in the species $C$. melo.

Dias et al. (2004) conducted a preliminary study on the genetics of some gross physical features related to root weight and length in an offspring $\left(\mathrm{F}_{1}, \mathrm{~F}_{2}, \mathrm{BC}_{1}\right.$, and $\left.\mathrm{BC}_{2}\right)$ derived from the cross C. melo ssp. melo 'Piel de sapo' (the main commercial type in Spain) $x$ C. melo ssp. agrestis Pat 81 . In that assay, young melon plants were characterized, and moderate values of broad- and narrow-sense heritabilities were found. The importance of additive effects confirmed the utility of some of the studied traits for roots selection. However, the traits analysed in this preliminary study did not accurately reflect the observed differences in root architecture between 'Piel de sapo' and Pat 81, and further studies at the architectural level are necessary.

The main goals of the present study were: 1) to define a set of useful traits in order to have a better understanding of the genetic control of root architecture at different levels, 2) to asses the genetics of traits related to root biomass and length in mature plants, as previously studied in young melon roots. Better estimates of heritabilities have now been obtained for all root traits using $\mathrm{F}_{3}$ families derived from the cross 'Piel de sapo' $x$ Pat 81.

\section{Materials and Methods}

Plant material. An $\mathrm{F}_{2}$ population was constructed from a cross between the melon cultivar Piel de sapo used as female, and the wild accession Pat 81 (held at the Center for the Conservation and Breeding of Agricultural Biodiversity Genebank, Valencia, Spain). The parental lines were obtained by manual crossing of full-siblings for several years, so they are inbreeding lines homozygous at most loci. A population of $91 \mathrm{~F}_{3}$ families were developed from randomly selected $\mathrm{F}_{2}$ individuals.

EXPERIMENTAL DESIGN. Working with a high number of adult plant roots is time-consuming and involves many technical difficulties, and is the reason why this study was carried out in a 2-year assay. Sixty-four and $41 \mathrm{~F}_{3}$ families were evaluated in 2003 and 2004, respectively. Twenty plants from each 'Piel de sapo', Pat 81 , and $\mathrm{F}_{1}$, and eight plants from each $\mathrm{F}_{3}$ generation, were evaluated. A total of 968 adult root systems were characterized. To estimate and correct the possible year effect and the year $\times$ family interaction effects on the root evaluation, $14 \mathrm{~F}_{3}$ families were evaluated both years.

Seeds were germinated in petri dishes. After 4-5 d, they were sown in 8 -kg pots (one plant per pot) with a sandy-loamy soil, disinfested with methyl bromide. Plants were arranged in a completely randomized design and grown in a greenhouse under controlled conditions $\left(25-35^{\circ} \mathrm{C}\right.$ day and $20-25^{\circ} \mathrm{C}$ night, relative humidity $60 \%$ to $70 \%$ day and $75 \%$ to $85 \%$ night, photoperiod $\approx 13-16$ h natural light and $8-11$ h dark). Plants were pruned in two stems and trained with vertical strings. They were drip irrigated twice per day for $5 \mathrm{~min}$. Fertilizer was applied with the irrigation water, at rate of $1 \mathrm{~g} \cdot \mathrm{L}^{-1}$ of a commercial $15 \mathrm{~N}-2.2 \mathrm{P}-24.9 \mathrm{~K}$ plus micronutrients.

ROOT CHARACTERIZATION. Roots were analyzed $\approx 80 \mathrm{~d}$. Once the vines were cut, the root systems were carefully extracted from the pots. The substrate was flushed with tap water. Each root was evaluated for different traits related to root biomass, root length, and root architecture. The two levels of root architecture proposed by Zobel (2005a, 2005b) were considered in this characterization: 1) the primary/secondary root system (mainly composed of mature roots involved in plant anchorage and in the support of the tertiary root system), 2) the tertiary root system (composed of fine roots that condition the functionality of mature root systems). The following traits were evaluated:

1) Root biomass: total root fresh weight [W (grams)], measured immediately after extracting and washing the roots; lateral root weight [LW (grams)], the weight of roots constituting the primary/secondary root system, measured after removing the fine roots (roots with a diameter of $\leq 0.5 \mathrm{~mm}$ ) these roots were removed by extending the complete root system on a graded paper (Fig. 1); fine root weight [FRW (grams)], the weight of roots with a diameter of $\leq 0.5 \mathrm{~mm}$, which constitute the tertiary root system.

2) Root length: the average length of three randomly chosen lateral roots ( $\mathrm{R} 1, \mathrm{R} 2, \mathrm{R} 3)$, originating from the tap root [L (centimeters)].

3) Root architecture, which was evaluated at two different levels: 1) at the primary/secondary root level: number of lateral roots (developed from the tap root and with a diameter of over $0.5 \mathrm{~mm}$ ) in each of the three thirds in which each root was divided using a imaginary line (Fig. 1), top (Nt), medium (Nm), and bottom $(\mathrm{Nb})$, and the average of $\mathrm{Nt}$ and $\mathrm{Nm}(\mathrm{NL}) ; 2)$ at the tertiary root level:branching level of the lateral roots (B), averaging the number of branches in R1, R2, and R3; root order (O), as described in Dias et al. (2002), averaging three observations in each R1, R2, and R3 (Fig. 2).

Statistical AND Genetic ANALYsis. The 14 control families employed both years were used in a factorial analysis of variance with two factors as well as in calculating Pearson correlations between years. Phenotypic correlations between all root traits analysed were calculated for all the families. Genetic correlations $\left(r_{g}\right)$ were estimated from the data obtained from the $F_{3}$ generation:

$$
r_{g}=\frac{\sigma_{b(x, y)}}{\sigma_{b(x)} \sigma_{b(y)}}
$$

where $\sigma_{b}(\mathrm{x}, \mathrm{y})$ is the covariance between $\mathrm{F}_{3}$ families for traits $\mathrm{x}$ and $\mathrm{y}$, while $\sigma_{\mathrm{b}}(\mathrm{x})$ and $\sigma_{\mathrm{b}}(\mathrm{y})$ are the standard deviations for the variance between $\mathrm{F}_{3}$ families for traits $\mathrm{x}$ and $\mathrm{y}$ (Ben-Chaim and Paran, 2000). The statistical significance of the genetic correlations was estimated using the method proposed by Hébert et al. (1994).

Broad-sense heritabilities $\left(\mathrm{h}^{2}{ }_{\mathrm{bs}}\right)$ were estimated by subtracting the environmental variance from the variance of the segregating generation $\mathrm{F}_{3}$ :

$$
\mathrm{h}_{\mathrm{bs}}^{2}=\frac{\mathrm{V}_{\mathrm{F}_{3}}-\mathrm{V}_{\mathrm{E}}}{\mathrm{V}_{\mathrm{F}_{3}}}
$$

where $\mathrm{V}_{\mathrm{E}}$ is the average phenotypic variance of the parentals, and $\mathrm{V}_{\mathrm{F}}$ is the phenotypic variance of the $\mathrm{F}_{3}$ generation (Ben-Chaim and Paran, 2000).

Standard errors for broad-sense heritabilities were calculated as the square root of the heritability variance, estimated as (Becker, 1984):

$$
V\left(h_{b s}^{2}\right)=V\left(\frac{x}{y}\right)=\frac{\left(y^{2} \times V_{x}\right)+\left(x^{2} \times V_{y}\right)-2[x \times y \times \operatorname{cov}(x, y)]}{y^{4}}
$$




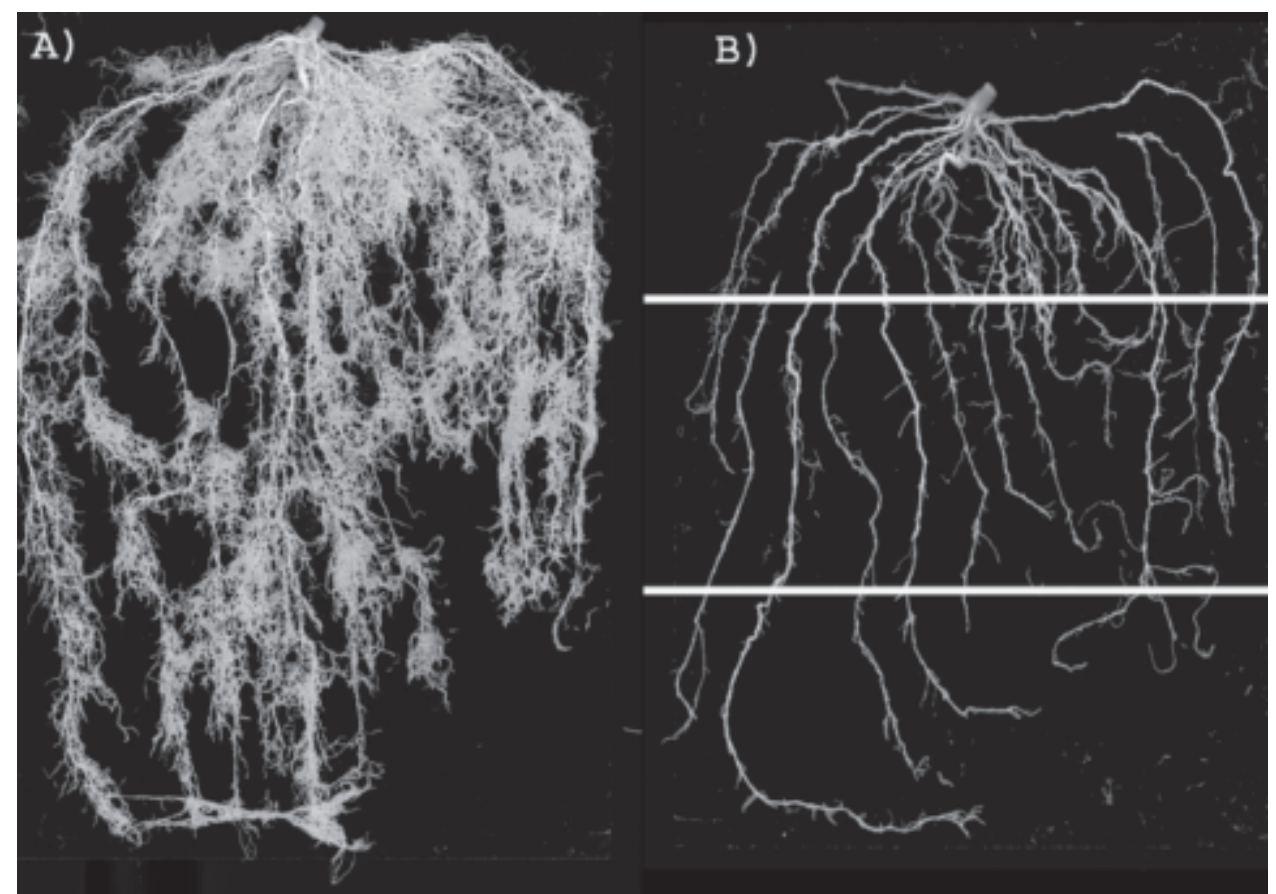

Fig. 1. Root system of 'Piel de sapo' melon grown in 8-kg pots for $80 \mathrm{~d}$ in a greenhouse assay. (A) entire root; (B) the same root after removing the fine roots (roots with diameter of $\leq 0.5 \mathrm{~mm}$ ) to measure the lateral root weight (LW). Lines indicate the three portions (top, medium, and bottom) in which each root was divided to count the number of lateral roots.

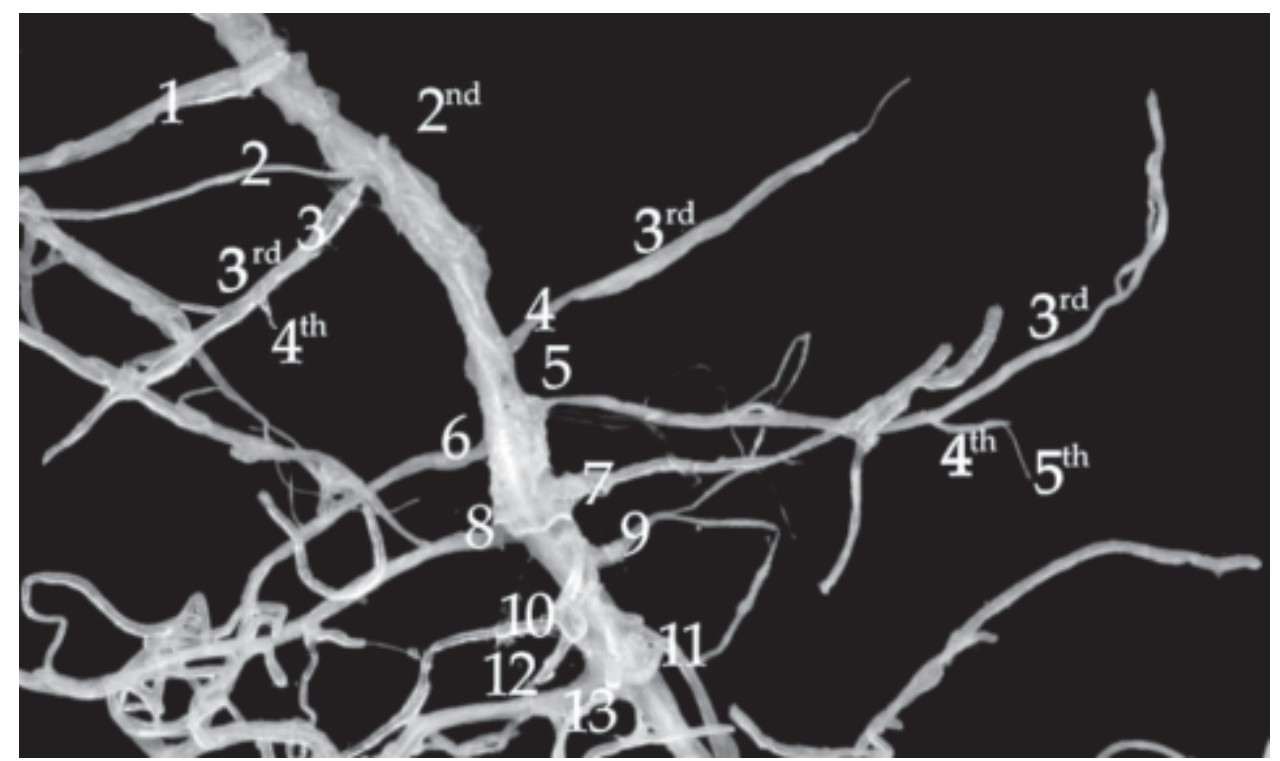

Fig. 2. Detail of one lateral root of the 'Piel de sapo' melon showing how to measure branching level, B, (numbers) and root order, $\mathrm{O}$, (ordinal numbers).

where $\mathrm{x}=\mathrm{V}_{\mathrm{g}}=\mathrm{V}_{\mathrm{F} 3}-\mathrm{V}_{\mathrm{E}}, \mathrm{y}=\mathrm{V}_{\mathrm{p}}=\mathrm{V}_{\mathrm{F} 3}, \mathrm{~V}_{\mathrm{x}}=\mathrm{V}\left(\mathrm{V}_{\mathrm{g}}\right), \mathrm{V}_{\mathrm{y}}=\mathrm{V}\left(\mathrm{V}_{\mathrm{p}}\right)$, $\operatorname{cov}(\mathrm{x}, \mathrm{y})=\operatorname{cov}\left(\mathrm{V}_{\mathrm{g}}, \mathrm{V}_{\mathrm{g}}+\mathrm{V}_{\mathrm{e}}\right)=\mathrm{V}\left(\mathrm{V}_{\mathrm{g}}\right)$ in this experiment.

Narrow-sense heritability $\left(\mathrm{h}^{2}{ }_{\mathrm{ns}}\right)$ was calculated with two different estimators. One proposed by Cahaner and Hillel (1980):

$$
h_{n s_{1}}^{2}=\frac{3}{2} \frac{\sigma_{b}^{2}}{\sigma_{b}^{2}+\sigma_{w}^{2}},
$$

where $\sigma_{\mathrm{b}}^{2}$ and $\sigma_{\mathrm{w}}^{2}$ are the variance between and within $\mathrm{F}_{3}$ families, respectively. This statistic is a bias by excess and is affected by both the dominant and the environmental variances. A second statistic that is less affected is:

$$
h_{n s 2}^{2}=\frac{\sigma_{b}^{2}}{\frac{1}{2} \sigma_{b}{ }_{b}+\sigma^{2}{ }_{w}}
$$

In both cases, the estimates of the standard error were calculated according to Kempthorne's method (Kempthorne, 1969).

\section{Results}

DesCriptive STATISTICS. According to the results of the factorial analysis, the year effect was significant in all traits (Table 1), 
Table 1. Analysis of variance results of the factorial analysis year $\times \mathrm{F}_{3}$ family for the different root traits analysed. The data obtained in a 2-year assay from the parents Cucumis melo ssp. melo 'Piel de sapo' and C. melo ssp. agrestis Pat 81 , the $\mathrm{F}_{1}$ and $14 \mathrm{~F}_{3}$ families (derived from the parental cross), have been used for the analysis.

\begin{tabular}{|c|c|c|c|c|c|c|c|c|}
\hline \multirow[b]{2}{*}{ Trait $^{z}$} & \multicolumn{2}{|c|}{$\mathrm{F}_{3}$ family } & \multicolumn{2}{|c|}{ Year } & \multicolumn{2}{|c|}{$\mathrm{F}_{3}$ family $\times$ year } & \multicolumn{2}{|c|}{ Residual } \\
\hline & df & $\begin{array}{l}\text { Mean } \\
\text { square }\end{array}$ & $\mathrm{df}$ & $\begin{array}{l}\text { Mean } \\
\text { square }\end{array}$ & $\mathrm{df}$ & $\begin{array}{l}\text { Mean } \\
\text { square }\end{array}$ & $\mathrm{df}$ & $\begin{array}{l}\text { Mean } \\
\text { square }\end{array}$ \\
\hline$\overline{\mathrm{Nt}}$ & 16 & $31.9^{*}$ & 1 & $5590^{*}$ & 16 & $19.8^{\mathrm{NS}}$ & 277 & 13.7 \\
\hline $\mathrm{Nm}$ & 16 & $41.1^{*}$ & 1 & $2303^{*}$ & 16 & $24.4^{\mathrm{NS}}$ & 288 & 16.45 \\
\hline $\mathrm{Nb}$ & 16 & $16.5^{*}$ & 1 & $106.2^{*}$ & 16 & $4.98^{\mathrm{NS}}$ & 288 & 16.4 \\
\hline NL & 16 & $32.4^{*}$ & 1 & $102.2^{*}$ & 16 & $14.2^{\mathrm{NS}}$ & 288 & 11.9 \\
\hline $\mathrm{L}(\mathrm{cm})$ & 16 & $210.7^{*}$ & 1 & $24228^{*}$ & 16 & $21.8^{\mathrm{NS}}$ & 310 & 55.1 \\
\hline B & 16 & $57.5^{*}$ & 1 & $3925^{*}$ & 16 & $14.4^{\mathrm{NS}}$ & 292 & 11.09 \\
\hline $\mathrm{O}$ & 16 & $0.876^{*}$ & 1 & $50.3^{*}$ & 16 & $0.149^{\mathrm{NS}}$ & 302 & 0.152 \\
\hline W (g) & 16 & $1415.5^{*}$ & 1 & $14649^{*}$ & 16 & $377.2^{\mathrm{NS}}$ & 283 & 336.9 \\
\hline FRW (g) & 16 & $70.8^{*}$ & 1 & $9953^{*}$ & 16 & $33.3^{\mathrm{NS}}$ & 273 & 23.0 \\
\hline LW (g) & 16 & $25.0^{*}$ & 1 & $136.4^{*}$ & 16 & $12.7^{\mathrm{NS}}$ & 273 & 9.5 \\
\hline
\end{tabular}

${ }^{2} \mathrm{Nt}, \mathrm{Nm}, \mathrm{Nb}=$ number of lateral roots in top, medium and bottom sections, respectively; $\mathrm{NL}=$ average of $\mathrm{Nt}$ and $\mathrm{Nm} ; \mathrm{B}=$ branching level of lateral roots; $\mathrm{O}=$ root order; $\mathrm{L}=$ root length; $\mathrm{W}=$ total root fresh weight; FRW $=$ fine roots weight $\mathrm{LW}=$ lateral roots weight.

Ns, *Nonsignificant or significant at $P<0.05$.

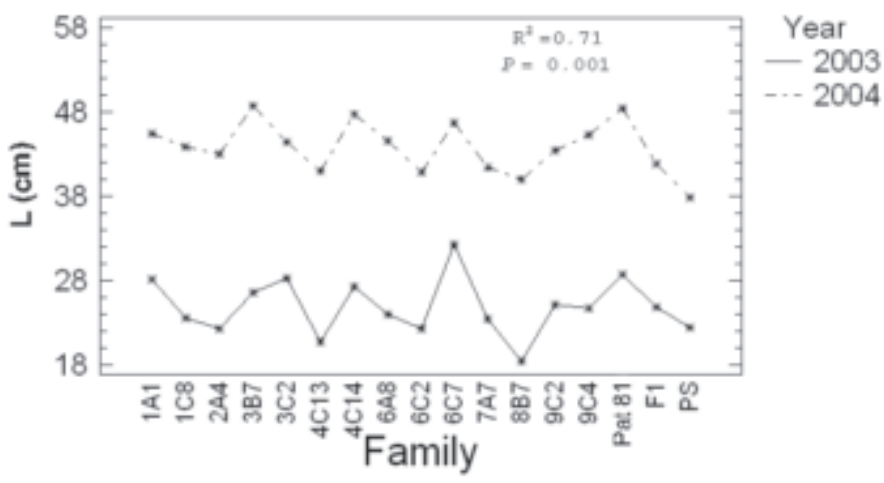

Fig. 3. Interaction year $\times \mathrm{F}_{3}$ family plot for root length $[\mathrm{L}(\mathrm{cm})]$, obtained from the ANOVA calculated using the data from the parents Cucumis melo ssp. melo 'Piel de sapo' and C. melo ssp. agrestis $\mathrm{Pat} 81$, the $\mathrm{F}_{1}$ and $14 \mathrm{~F}_{3}$ families (derived from the parental cross) in a 2-year assay. Mean values obtained both years for the $14 \mathrm{~F}_{3}$ common families, parents and $\mathrm{F}_{1}$ are indicated.

although year $\times \mathrm{F}_{3}$ family interactions were not significant for any studied trait as shown in Fig. 3. The values of Pearson correlation ( $r$ ) between years were significantly positive for all the analyzed traits (data not shown). According to this correlation, traits related to root architecture and length were more stable ( $\mathrm{r}$ ranging from 0.52 to 0.75 for $\mathrm{Nt}$ and $\mathrm{L}$, respectively) than traits related to root biomass ( $\mathrm{r}$ ranging from 0.40 to 0.47 for $\mathrm{BW}$ and LW, respectively).

These results indicate that all the traits studied experienced significant changes in their values from one year to another. However, within each particular trait, these changes showed the same tendency in all of the control families, as indicated by the absence of significant year $\times$ family interactions. Because of this, and in order to use the values recorded both years, the values were standardized by taking into account the year effect.

Pat 81 had significantly higher values than 'Piel de sapo' for all length and architectural traits, although the values for biomass traits were lower in Pat 81 than in 'Piel de sapo' (Table 2 and Fig. 4). For most traits, the mean values of the $F_{1}$ generation were intermediate among parentals. However, transgressive means for $\mathrm{Nt}, \mathrm{Nm}, \mathrm{Nb}$, and $\mathrm{NL}$ were found. The $\mathrm{F}_{3}$ means were intermediate among parentals, and were lower than the $\mathrm{F}_{1}$ means in all cases.
Heritability of roOt TRAits. Heritabilities were calculated using standardized data from both years. Broad-sense heritabilities were low to moderate, ranging from 0.26 to 0.54 (Table 3 ), which indicates the importance of factors that are not genetic in nature (environmental fluctuations, experimental errors...) on the phenotiphic variation observed in the traits examined. The highest $\mathrm{h}^{2}{ }_{\mathrm{bs}}$ estimates were found in $\mathrm{W}, \mathrm{LW}$ and in $\mathrm{L}\left(\mathrm{h}^{2}{ }_{\mathrm{bs}}>0.40\right)$, while $\mathrm{B}$ and FRW showed the lowest values $\left(\mathrm{h}_{\mathrm{bs}}^{2}=0.26\right)$. The rest of the traits showed intermediate $\mathrm{h}^{2}$ bs values $\left(0.30<\mathrm{h}^{2}{ }_{\mathrm{bs}} \leq\right.$ 0.40 ) (Table 3 ). Narrow-sense heritabilities ranged from very low values to moderate values $\left(0.10>\mathrm{h}^{2}{ }_{\mathrm{ns}}>0.32\right)$. The traits with the lowest $\mathrm{h}^{2}$ vs values were root biomass traits (W, FRW), while the highest $\mathrm{h}^{2}{ }_{\mathrm{ns}}$ values were found in the number of lateral roots (Nt, $\mathrm{Nm}, \mathrm{Nb}, \mathrm{NL})$. Root length (L) and architectural traits related to the tertiary root system $(\mathrm{B}, \mathrm{O})$ displayed intermediate $\mathrm{h}^{2}{ }_{\mathrm{ns}}$ values. The differences between $\mathrm{h}^{2}{ }_{\mathrm{bs}}$ and $\mathrm{h}^{2}{ }_{\mathrm{ns}}$ indicate the importance of dominance in root biomass parameters. Additive effects were most important in root length and architectural parameters, mostly in those of the primary/secondary root system. The results obtained with both formulas were concordant, providing two estimates of narrow-sense heritabilities.

PhenOTYPIC AND GENETIC CORRELATIONS BETWEEN ROOT TRAITS. Partial correlations ( $\mathrm{pc}$ ) and Pearson correlations ( $\mathrm{r}$ ) between root traits were low to moderate. Within the architectural parameters, the correlation was moderate between $\mathrm{Nt}$ and $\mathrm{Nm}(\mathrm{pc}=0.38, \mathrm{r}$ $=0.46, P<0.01)$, and low between these traits and $\mathrm{Nb}(\mathrm{pc}=$ $0.15-0.20, \mathrm{r}=0.28, P<0.01)$, and between $\mathrm{B}$ and $\mathrm{O}(\mathrm{pc}=0.31$, $\mathrm{r}=0.33, P<0.01)$. Parameters related to the primary/secondary root system (Nt, Nm, Nb, and NL) were not correlated with those of the tertiary root system (B and O). Significant, but low correlations were found between root length $(\mathrm{L})$ and the number of lateral roots at the bottom section $\mathrm{Nb}(\mathrm{pc}=0.32, \mathrm{r}=0.31, P$ $<0.01)$ and root biomass traits, $\mathrm{W}$ and LW ( $\mathrm{pc}=0.08-0.05, \mathrm{r}=$ $0.15-0.12, P<0.01$, respectively). Root fresh weight (W) had a higher correlation with the weight of fine roots $(\mathrm{FRW})(\mathrm{pc}=0.51$, $\mathrm{r}=0.53, P<0.01)$ than with the weight of lateral roots $(\mathrm{LW})(\mathrm{pc}$ $=0.09, \mathrm{r}=0.22, P<0.01)$. There were no significant correlations between biomass traits (W, LW, FRW) and architectural parameters (NL, B, O).

Genetic correlations were only significant in a few cases. Nt, $\mathrm{Nm}$ and NL displayed moderate to high genetic correlations $\left(\mathrm{r}_{\mathrm{g}}\right.$ 
Table 2. Means and standard errors from the parents Cucumis melo ssp. melo 'Piel de sapo' and $C$. melo ssp. agrestis Pat 81 , the $\mathrm{F}_{1}$ and $\mathrm{F}_{3}$ derived from their cross, for the different root traits analysed in a 2-year assay.

\begin{tabular}{lcccc}
\hline Traits $^{z}$ & Pat 81 & 'Piel de sapo' & $\mathrm{F}_{1}$ & $\mathrm{~F}_{3}$ \\
\hline $\mathrm{Nt}$ & $19.3 \mathrm{a}^{\mathrm{y}} \pm 0.7$ & $14.6 \mathrm{~b} \pm 0.5$ & $19.6 \mathrm{a} \pm 0.7$ & $15.1 \pm 0.14$ \\
$\mathrm{Nm}$ & $19.6 \mathrm{a} \pm 0.6$ & $15.5 \mathrm{~b} \pm 0.6$ & $20.7 \mathrm{a} \pm 0.7$ & $17.9 \pm 0.15$ \\
$\mathrm{Nb}$ & $6.7 \mathrm{a} \pm 0.3$ & $4.6 \mathrm{~b} \pm 0.3$ & $7.9 \mathrm{a} \pm 0.5$ & $5.1 \pm 0.07$ \\
$\mathrm{NL}$ & $19.3 \mathrm{a} \pm 0.5$ & $15.0 \mathrm{~b} \pm 0.4$ & $20.2 \mathrm{a} \pm 0.6$ & $16.6 \pm 0.13$ \\
$\mathrm{Nb} / \mathrm{NL}$ & $0.36 \mathrm{~b} \pm 0.02$ & $0.29 \mathrm{a} \pm 0.02$ & $0.38 \mathrm{~b} \pm 0.02$ & $0.31 \pm 0.005$ \\
$\mathrm{~B}$ & $15.9 \mathrm{a} \pm 0.5$ & $10.8 \mathrm{c} \pm 0.05$ & $13.3 \mathrm{~b} \pm 0.6$ & $11.5 \pm 0.12$ \\
$\mathrm{O}$ & $5.2 \mathrm{a} \pm 0.05$ & $4.4 \mathrm{c} \pm 0.06$ & $5.0 \mathrm{~b} \pm 0.05$ & $4.7 \pm 0.01$ \\
$\mathrm{~L}(\mathrm{~cm})$ & $39.6 \mathrm{a} \pm 1.1$ & $30.0 \mathrm{c} \pm 0.8$ & $33.4 \mathrm{~b} \pm 1.3$ & $33.7 \pm 0.23$ \\
$\mathrm{~W}(\mathrm{~g})$ & $47.7 \mathrm{a} \pm 2.1$ & $71.0 \mathrm{c} \pm 2.5$ & $63.6 \mathrm{~b} \pm 2.1$ & $56.2 \pm 0.69$ \\
$\mathrm{FRW}(\mathrm{g})$ & $12.9 \mathrm{a} \pm 0.6$ & $19.0 \mathrm{c} \pm 1$ & $16.2 \mathrm{~b} \pm 0.8$ & $14.5 \pm 0.19$ \\
$\mathrm{LW}(\mathrm{g})$ & $7.3 \mathrm{a} \pm 0.3$ & $9.3 \mathrm{~b} \pm 0.6$ & $9.4 \mathrm{~b} \pm 0.5$ & $7.73 \pm 0.13$ \\
\hline
\end{tabular}

${ }^{2} \mathrm{Nt}, \mathrm{Nm}, \mathrm{Nb}=$ number of lateral roots in three portions (top, medium, and bottom) respectively; $\mathrm{NL}=$ average of $\mathrm{Nt}$ and $\mathrm{Nm} ; \mathrm{B}=$ branching level of lateral roots; $\mathrm{O}=$ root order; $\mathrm{L}=$ root length; $\mathrm{W}=$ total root fresh weight; FRW = fine roots weight; $\mathrm{LW}=$ lateral roots weight. yNumbers in the same row with different superscript letters differ significantly at $P<0.05$ by Duncan's multiple range test.

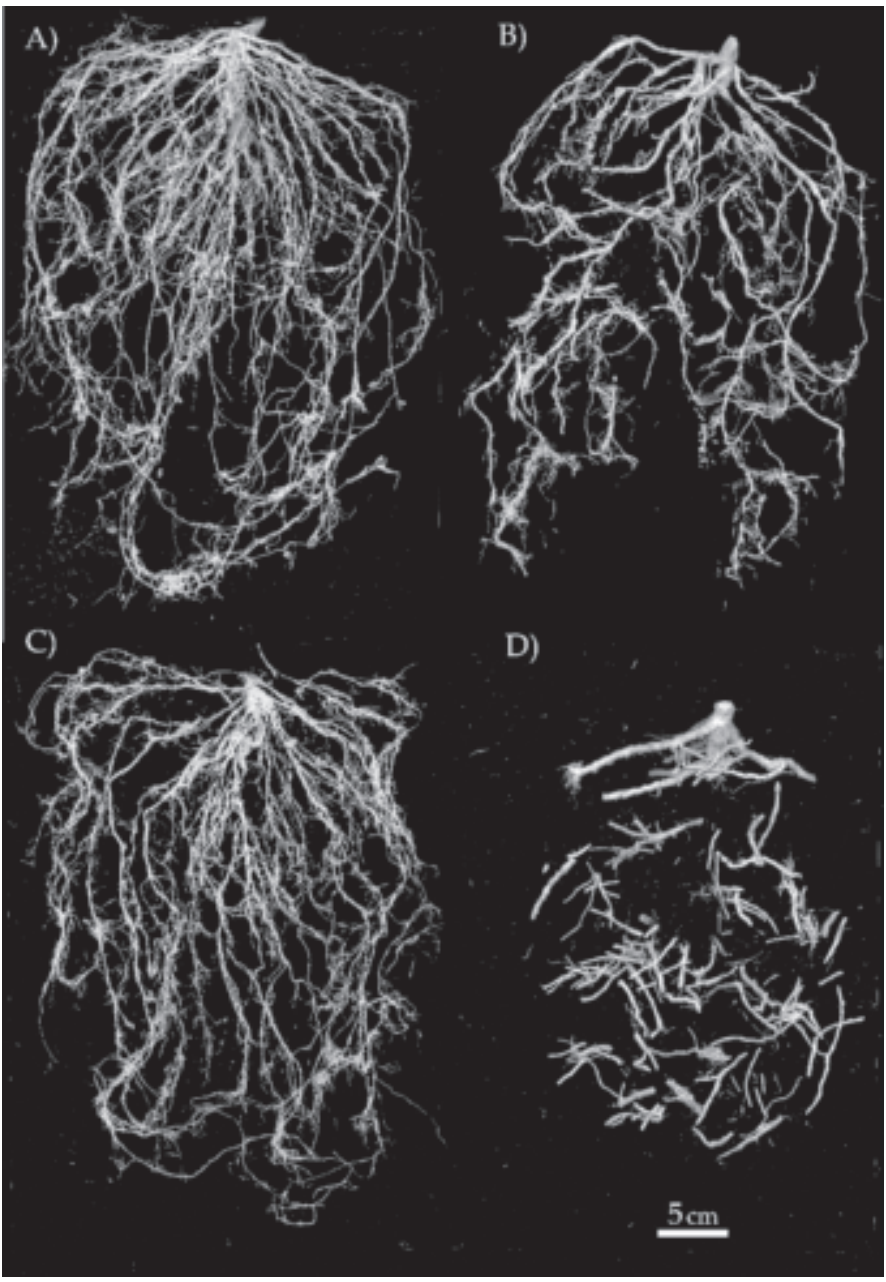

Fig. 4. Melon root systems of 80-d-old plants grown in 8-kg pots in a greenhouse (after removing the fine roots, $\leq 0.5 \mathrm{~mm}$ in diameter). (A and $\mathbf{B}$ ) Root systems of Cucumis melo ssp. agrestis Pat 81 and C. melo ssp. melo 'Piel de sapo' plants, respectively, grown in sterile soil. (C and D) Root systems of Pat 81 and 'Piel de sapo' plants, respectively, grown in Monosporascus cannonballusinfested soil. ranging from 0.59 to $0.89, P<0.01$ ), but were not correlated with $\mathrm{Nb}$, nor with the parameters of the tertiary root system. We also found a strong genetic correlation between $\mathrm{B}$ and $\mathrm{O}\left(\mathrm{r}_{\mathrm{g}}=0.73\right.$, $P<0.01)$, much higher than the phenotypic correlation. Genetic correlations between root length $(\mathrm{L})$ and root biomass were moderate, but higher than the phenotypic correlations $\left(\mathrm{r}_{\mathrm{g}}=0.50, P<0.01 ; \mathrm{r}_{\mathrm{g}}=0.54, P<0.01\right.$ for $\mathrm{W}$ and LW, respectively). L was also genetically correlated to $\mathrm{Nb}\left(\mathrm{r}_{\mathrm{g}}=0.81, P<0.01\right)$. W was genetically correlated with FRW $\left(\mathrm{r}_{\mathrm{g}}=0.53, P\right.$ $<0.01$ ), but not with LW, and there were not significant genetic correlations between root biomass and architecture traits, as occurred with the phenotypic correlations.

\section{Discussion}

This study demonstrates that Pat 81 , a wild melon accession resistant to the soil-borne pathogen M. cannonballus, has in pathogen-free soils differential root features (biomass, length and architecture) in comparison with 'Piel de sapo', a cultivated type highly susceptible to this pathogen (Fig. 4). Despite the high plasticity of root systems and the difficulty of evaluating mature root systems the results found are in concordance with those previously obtained in young plants for most traits, except for that which measures root biomass. Dias et al. (2004) reported a root fresh weight in young plants of Pat 81 greater than that of 'Piel de sapo'. However, in our experiments, the mature roots of 'Piel de sapo' had greater biomass than Pat 81. The heritabilities found for these traits in mature plants support the existence of strong environmental effects and indicate the importance of dominant effects. The dominant variance although useful in plant breeding difficults the plant management during the selection program. It is less fixable than additive variance and must be exploited through the hybrid vigor. The dominant nature of biomass traits, along with the lack of stability may hamper their use in breeding programs. Additionally, many authors think that selecting plants with greater overall root biomass would likely negatively impact yield and would not ensure a higher capacity of soil exploration (Clarke and McCaig, 1993). Of two plants with identical biomass, the plant with a root structure that exploits the largest possible soil volume may acquire water and nutrients and escape soil-borne diseases more efficiently (Hund et al., 2004; Johnson et al., 2000). Our results support these statements. The higher root biomass of mature 'Piel de sapo' plants does not imply for this genotype favorable features in length nor architectural parameters. For example, the greater weight of lateral roots (LW) does not come from a higher number of laterals nor from longer ones, but from thicker lateral roots (LW/NL is in 'Piel de sapo', $0.62 \mathrm{~g}$ per lateral root, nearly 2-fold higher than in Pat 81, $0.38 \mathrm{~g}$ per lateral root). The lack of phenotypic and genetic correlation between root biomass and root architecture in the $\mathrm{F}_{3}$ population also supports this point.

We found root length to be more stable than root biomass both between years and between plant developmental stages. Both young (Dias et al., 2004) and mature plants of Pat 81 developed roots significantly longer than 'Piel de sapo'. Heritability values also indicate strong environmental effects on root length. However, the dominant component was less important in comparison with root biomass. Its additive nature, coupled with its higher stability, 
Table 3. Estimates of the broad-sense heritability $\left(\mathrm{h}^{2}{ }_{\mathrm{bs}} \pm \mathrm{SE}\right)$ and two estimates of narrow-sense heritability $\left(\mathrm{h}^{2}{ }_{\mathrm{ns} 1} \pm \mathrm{SE}\right.$ and $\left.\mathrm{h}_{\mathrm{ns} 2}^{2} \pm \mathrm{SE}\right)$ obtained from the data of a 2-year assay in which the roots of the parents Cucumis melo ssp. melo 'Piel de sapo' and C. melo ssp. agrestis Pat 81, the $\mathrm{F}_{1}$ and $\mathrm{F}_{3}$ derived from their cross, were characterized.

\begin{tabular}{lccc}
\hline Traits $^{\mathrm{z}}$ & $\mathrm{h}_{\mathrm{bs}}^{2}$ & $\mathrm{~h}^{2}{ }_{\mathrm{n} 1}$ & $\mathrm{~h}^{2}{ }_{\mathrm{ns} 2}$ \\
\hline $\mathrm{Nt}$ & $0.33 \pm 0.06$ & $0.30 \pm 0.06$ & $0.23 \pm 0.05$ \\
$\mathrm{Nm}$ & $0.40 \pm 0.06$ & $0.28 \pm 0.05$ & $0.21 \pm 0.04$ \\
$\mathrm{Nb}$ & $0.37 \pm 0.07$ & $0.31 \pm 0.06$ & $0.23 \pm 0.05$ \\
$\mathrm{NL}$ & $0.36 \pm 0.07$ & $0.32 \pm 0.06$ & $0.24 \pm 0.05$ \\
$\mathrm{Nb} / \mathrm{NL}$ & $0.39 \pm 0.03$ & $0.29 \pm 0.06$ & $0.22 \pm 0.05$ \\
$\mathrm{~B}$ & $0.26 \pm 0.09$ & $0.18 \pm 0.04$ & $0.13 \pm 0.03$ \\
$\mathrm{O}$ & $0.38 \pm 0.06$ & $0.20 \pm 0.05$ & $0.14 \pm 0.04$ \\
$\mathrm{~L}(\mathrm{~cm})$ & $0.44 \pm 0.06$ & $0.25 \pm 0.05$ & $0.18 \pm 0.04$ \\
$\mathrm{~W}(\mathrm{~g})$ & $0.54 \pm 0.04$ & $0.14 \pm 0.04$ & $0.10 \pm 0.03$ \\
$\mathrm{FRW}(\mathrm{g})$ & $0.26 \pm 0.1$ & $0.14 \pm 0.04$ & $0.10 \pm 0.03$ \\
$\mathrm{LW}(\mathrm{g})$ & $0.43 \pm 0.07$ & $0.21 \pm 0.05$ & $0.15 \pm 0.04$ \\
\hline
\end{tabular}

${ }^{2} \mathrm{Nt}, \mathrm{Nm}, \mathrm{Nb}=$ number of lateral roots in top, medium and bottom sections, respectively; $\mathrm{NL}=$ average of $\mathrm{Nt}$ and $\mathrm{Nm} ; \mathrm{B}=$ branching level of lateral roots; $\mathrm{O}=$ root order; $\mathrm{L}=$ root length; $\mathrm{W}=$ total root fresh weight; $\mathrm{FRW}=$ fine roots weight; $\mathrm{LW}=$ lateral roots weight.

makes root length more reliable for root selection. Longer roots are desirable as a higher root length may be associated to deeper rooting. Deeper root systems are able to reach lower layers of the soil profile that in some soil environments can be richer in water and some nutrients. In fact, root length has been widely used to improve vegetables against drought stress (Pace et al., 1999; Price et al., 1997). The access to deeper soil zones may also allow the plant to avoid biotic soil stresses by exploring soil layers less infested with pathogens. The success of selection based on root length depends on the heritabilities and on the correlations with other favorable or unfavorable root traits. Root length was only moderately correlated with root biomass, which suggests that rooting deep can be increased without causing a significant alteration of root biomass. A preliminary selection assay was performed to demonstrate the utility of this parameter in programs for breeding root systems. Despite the moderate heritabilities, a realized heritability of 0.34 was obtained by selfing the selected individuals in an $\mathrm{F}_{2}$ population (using a selection pressure of $10 \%$ ).

Our results demonstrate that in adult states Pat 81 and 'Piel de sapo' also differ greatly in root architecture. This is the first study in which the genetics of root architecture in melons is character- ized at the different levels as defined by Zobel (2005a, 2005b). In previous studies using melon seedlings (Dias et al., 2002; R. de C.S. Dias, unpublished data), we evaluated root architecture by employing different visual scores. With these indices, we consistently observed a more branched root system in Pat 81 in comparison with different types of cultivated melons belonging to the subspecies melo. This suggests the stability of root architecture between seedlings and mature plants. The additive effects found in architectural traits and the lack of phenotypic and genetic correlations between architectural parameters and root biomass or length suggest that root architecture can be successfully improved without altering the other root parameters.

According to Zobel (2005a) the ultimate function of the primary/secondary root system is to anchor the plant, to extend the size of the root system and to act as passive pipes in the interchange of water, nutrients and carbohydrates between shots and roots. Primary and secondary roots would act as "framework" roots (Wells and Eissenstat, 2003) supporting higher order roots that would constitute the tertiary root system. From this point of view, the roots of Pat 81 have a favorable primary/secondary root system with a high density of framework roots, more uniformly distributed along the soil profile than 'Piel de sapo', which provides the basis for an increased growth of absorptive roots. Additionally, and independent from this potential, Pat 81 has a favorable tertiary root system with a higher density of branches per lateral and a higher number of root orders. In many annual crop species, the number of root orders appears to be relatively fixed. However, this characteristic has received little attention, mainly because it is very difficult to measure (Wells and Eissenstat, 2003).

The lack of phenotypic and genetic correlations between architectural traits measuring the primary/secondary root system and those which refer to the tertiary root system supports the existence of a differential genetic control for both groups of traits, which has already been suggested by Zobel (2005a, 2005b). The different values for broad- and narrow-sense heritabilities also support an independent genetic control. In general, broad-sense heritabilities were higher for primary/secondary root traits, indicating that they are less affected by the environment. The narrow-sense heritabilities for these traits were the highest among the root traits analysed. Most of the variation for these traits could be explained by additive effects, whereas dominance is still important in traits which refer to the tertiary root system. The preliminary selection assay in an $\mathrm{F}_{2}$ population provided

Table 4. Correlations among the root traits obtained from the data of a 2-year assay in which the roots of the parents Cucumis melo ssp. melo 'Piel de sapo' and C. melo ssp. agrestis Pat 81 , the $\mathrm{F}_{1}$ and $\mathrm{F}_{3}$ derived from their cross, were characterized. Genetic correlation (above diagonal), phenotypic correlation (below diagonal).

\begin{tabular}{|c|c|c|c|c|c|c|c|c|c|c|}
\hline Traits $^{z}$ & $\begin{array}{l}\text { W } \\
(\mathrm{g})\end{array}$ & $\begin{array}{c}\text { FRW } \\
(\mathrm{g})\end{array}$ & $\begin{array}{l}\text { LW } \\
(\mathrm{g})\end{array}$ & $\begin{array}{c}\mathrm{L} \\
(\mathrm{cm})\end{array}$ & B & $\mathrm{O}$ & $\mathrm{Nt}$ & $\mathrm{Nm}$ & $\mathrm{Nb}$ & NL \\
\hline$\overline{\mathrm{W}(\mathrm{g})}$ & & $0.53^{* * *}$ & $0.32^{\mathrm{NS}}$ & $0.50^{* * *}$ & $0.06^{\mathrm{NS}}$ & $0.002^{\mathrm{NS}}$ & $-0.10^{\mathrm{NS}}$ & $0.06^{\mathrm{NS}}$ & $0.49^{* *}$ & $0.12^{\mathrm{NS}}$ \\
\hline FRW (g) & $0.53^{* * *}$ & & $-0.005^{\mathrm{NS}}$ & $0.16^{\mathrm{NS}}$ & $-0.22^{\mathrm{NS}}$ & $0.005^{\mathrm{NS}}$ & $-0.009^{\mathrm{NS}}$ & $0.06^{\mathrm{NS}}$ & $0.11^{\mathrm{NS}}$ & $0.04^{\mathrm{NS}}$ \\
\hline LW (g) & $0.22^{* * *}$ & $0.24^{* * *}$ & & $0.54^{* * *}$ & $-0.09^{\mathrm{NS}}$ & $0.005^{\mathrm{NS}}$ & $0.15^{\mathrm{NS}}$ & $0.16^{\mathrm{NS}}$ & $0.23^{\mathrm{NS}}$ & $0.15^{\mathrm{NS}}$ \\
\hline $\mathrm{L}(\mathrm{cm})$ & $0.15^{* * * *}$ & $0.06^{\mathrm{NS}}$ & $0.12^{* * * *}$ & & $-0.08^{\mathrm{NS}}$ & $0.30^{\mathrm{NS}}$ & $-0.11^{\mathrm{NS}}$ & $0.21^{\mathrm{NS}}$ & $0.81^{\mathrm{NS}}$ & $0.06^{\mathrm{NS}}$ \\
\hline B & $0.04^{\mathrm{NS}}$ & $0.02^{\mathrm{NS}}$ & $0.05^{\mathrm{NS}}$ & $0.19^{* * *}$ & & $0.73^{* * * *}$ & $-0.23^{\mathrm{NS}}$ & $-0.10^{\mathrm{NS}}$ & $0.001^{\mathrm{NS}}$ & $-0.16^{\mathrm{NS}}$ \\
\hline $\mathrm{O}$ & $-0.01^{\mathrm{NS}}$ & $-0.01^{\mathrm{NS}}$ & $0.04^{\mathrm{NS}}$ & $0.14^{* * * *}$ & $0.33^{* * * *}$ & & $0.31^{* * *}$ & $-0.15^{\mathrm{NS}}$ & $0.24^{\mathrm{NS}}$ & $-0.18^{\mathrm{NS}}$ \\
\hline $\mathrm{Nt}$ & $0.10^{*}$ & $0.06^{\mathrm{NS}}$ & $0.18^{* * *}$ & $0.04^{\mathrm{NS}}$ & $0.13^{* * * *}$ & $0.08^{*}$ & & $0.59^{* * * *}$ & $0.14^{\mathrm{NS}}$ & $0.76^{\text {**** }}$ \\
\hline $\mathrm{Nm}$ & $0.09^{*}$ & $0.07_{\mathrm{NS}}$ & $0.22^{* * * *}$ & $0.02^{\mathrm{NS}}$ & $0.03^{\mathrm{NS}}$ & $0.09^{*}$ & $0.46^{* * *}$ & & $0.31^{\mathrm{NS}}$ & $0.89^{\text {*** }}$ \\
\hline $\mathrm{Nb}$ & $0.11^{* * * *}$ & $0.03^{\mathrm{NS}}$ & $0.19^{* * * *}$ & $0.31^{* * *}$ & $0.06^{\mathrm{NS}}$ & $0.08^{*}$ & $0.28^{* * *}$ & $0.28^{* * *}$ & & $0.30^{\mathrm{NS}}$ \\
\hline NL & $0.10^{* * * *}$ & $0.07^{*}$ & $0.24^{* * * *}$ & $0.04^{\mathrm{NS}}$ & $0.09^{*}$ & $0.09^{* *}$ & $0.84^{* * *}$ & $0.87^{* * * *}$ & $0.34^{* * *}$ & \\
\hline
\end{tabular}

$\overline{\mathrm{z}} \mathrm{W}=$ total root fresh weight; FRW = fine roots weight; $\mathrm{LW}=$ lateral roots weight; $\mathrm{Nt}, \mathrm{Nm}, \mathrm{Nb}=$ number of lateral roots in top, medium and bottom sections, respectively; $\mathrm{NL}=$ average of $\mathrm{Nt}$ and $\mathrm{Nm} ; \mathrm{B}=$ branching level of lateral roots; $\mathrm{O}=$ root order; $\mathrm{L}=$ root length.

Ns, *,*****Nonsignificant or significant at $P<0.05,0.01$, or 0.001 level, respectively. 
A)

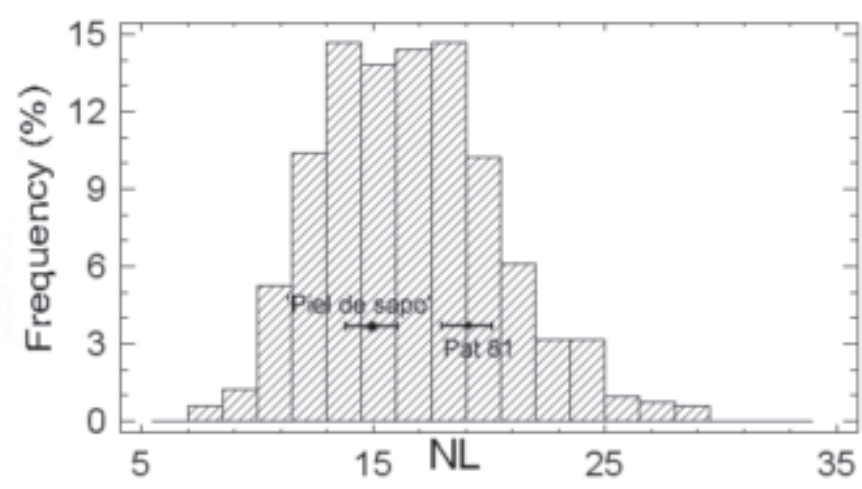

B)

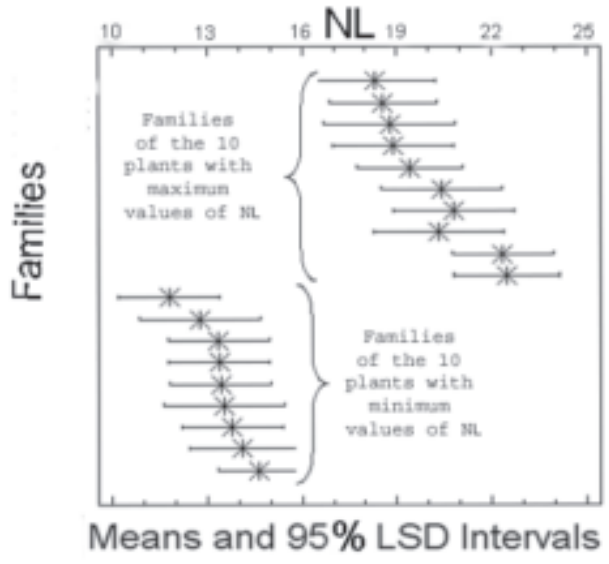

Fig. 5. Analysis of the average number of lateral roots in top and medium sections (NL) in the $\mathrm{F}_{3}$ individuals derived from a cross between Cucumis melo ssp. melo 'Piel de sapo' and C. melo ssp. agrestis Pat 81. (A) Frequency histograms for all $\mathrm{F}_{3}$ individuals, mean and LSD interval for 'Piel de sapo' and Pat 81 . (B) Means and LSD intervals of the families to which belong the $10 \mathrm{~F}_{3}$ individuals from the $\mathrm{F}_{3}$ generation which showed the 10 extreme maximum and minimum values of NL.

a realized heritability of 0.25 for NL, which demonstrates the success in using architectural parameters.

Searching QTLs for root traits is a common practice (Tuberosa et al., 2003; Zheng et al., 2003; Zhu et al., 2005). The complexity of architectural traits may be explained by quantitative genetic parameters more efficiently than by single-gene approaches (Lynch, 1995). However, on occasion a single genetic control could be masked by the variation associated with the difficulty in studying roots (Bushamuka et al., 1998; Fitz Gerald et al., 2006). In this regard, we have performed an additional analysis for the number of lateral roots (NL), as this is the most reliable trait in our study. First, $10 \mathrm{~F}_{3}$ individuals showing the lowest $\mathrm{NL}$ values and $10 \mathrm{~F}_{3}$ individuals showing the highest NL values were selected. Then we represented the family-mean values of NL corresponding to these individuals (Fig. 5). We found that $\mathrm{F}_{3}$ families corresponding to the individuals with the lowest values showed low mean values too, and that these means were significantly lower than those corresponding to $\mathrm{F}_{3}$ families of individuals with the highest NL values. The lower is the number of genes controlling this trait, the higher is the probability of finding low variability within the family to which each extreme individual belong. These results suggest that the genetic control of the number of laterals might be simpler than previously supposed. Experimental errors, environmental influences and root plasticity can mask this simple genetic control, conferring the trait a quantitative appearance.

In conclusion, in order to achieve positive results in breeding plants for improved root systems, first we must define a plant ideotype which includes the root features that we consider favorable for our breeding objectives. Melon plants with a root architecture that exploits the largest possible soil volume (long laterals uniformly distributed along the soil profile with high root orders) without increasing carbon expenditures (without an increase in overall root biomass) would be optimal for production under both high-input and stressful growing conditions. It would seem to be possible to achieve this root ideotype using Pat 81 as an allele donor for increasing root length and altering the root architecture of cultivated melon.

\section{Literature Cited}

Ben-Chaim, A. and I. Paran. 2000. Genetic analysis of quantitative traits in pepper (Capsicum annuum). J. Amer. Soc. Hort. Sci. 125:66-70.

Becker, W.A. 1984. Manual of quantitative genetics. Academic Enterprises, Pullman, Wash.

Cahaner,A. and J. Hillel. 1980. Estimating heritability and genetic correlation between traits from generations $\mathrm{F}_{2}$ and $\mathrm{F}_{3}$ of self-fertilizing species: A comparison of three methods. Theor. Appl. Genet. 58:33-38

Chapin, F.S., R.H. Groves, and L.T. Evans. 1989. Physiological determinants of growth-rate in response to phosphorus supply in wild and cultivated Hordeum species. Oecologia 79:96-105

Clarke, J.M. and T.N. McCaig. 1993. Breeding for efficient root systems, p. 485-499. In: M.D. Hayward, N.O. Bosemark, and I. Romagosa (eds.) Plant breeding: Principles and prospects. Chapman and Hall, London.

Crosby, K. 2000. Narrow-sense heritability estimates for root traits and Monosporascus cannonballus tolerance in melon (Cucumis melo) by parent-offspring regression. Proc. Cucurbitaceae 2000. Acta Hort. 510:149-153.

Crosby, K., D. Wolff, and M. Miller. 2000. Comparison of root morphology in susceptible and tolerant melon cultivars before and after infection by Monosporascus cannonballus. HortScience 35:681-683

Dias, R. de C.S., B. Picó, J. Herraiz, A. Espinós, and F. Nuez. 2002. Modifying root structure of cultivated muskmelon to improve vine decline resistance. HortScience 37:1092-1097.

Dias, R. de C.S., B. Picó, A. Espinós, and F. Nuez. 2004. Resistance to melon vine decline derived from Cucumis melo ssp. agrestis: Genetic analysis for root structure and root response. Plant Breeding 123:66-72

Esteva, J. and F. Nuez. 1994. Field resistance to melon dieback in $\mathrm{Cu}$ cumis melo L. Cucurbit Genet. Coop. 17:76-77.

Fitz Gerald, J.N., M.D. Lehti-Shiu, P.A. Ingram, K.I. Deak, T. Biesiada, and J.E. Malamy. 2006. Quantitative trait loci that regulate arabidopsis root system size and plasticity. Genetics 172:485-498.

Hébert, D., S. Fauré, and I. Olivieri. 1994. Genetic, phenotypic and environmental correlations in black medic, Medicago lupulina L., grown in three different environments. Theor. Appl. Genet. 88:604-613.

Hund, A., Y. Frachedboud, A. Soldati, E. Frascaroli, S. Salvi, and P. Stamp. 2004. QTL controlling root and shoot traits of maize seedlings under cold stress. Theor. Appl. Genet. 109:618-629.

Iglesias, A. and F. Nuez. 1998. Caracterización de diversas entradas de melón frente al colapso o muerte súbita. Actas de Horticultura 22:139-147.

Iglesias, A., B. Picó, and F. Nuez. 1999. Resistance to melon dieback in Cucumis melo ssp. agrestis Pat 81. Phytopathology 89:S35. (Abstr.)

Iglesias, A., B. Picó, and F. Nuez. 2000a. A temporal genetic analisis of disease resistance genes: Resistance to melon vine decline derived from Cucumis melo var agrestis. Plant Breeding 118:1-6.

Iglesias, A., B. Picó, and F. Nuez. 2000b. Artificial inoculation methods and selection criteria for breeding melons against vine decline. Acta Hort. 510:155-162. 
Jackson,L.E. and G.W. Koch. 1997. The ecophysiology of crops and their wild relatives, p. 3-37. In: L.E. Jackson (ed.). Ecology in agriculture. Academic, San Diego.

Jeffrey, C. 1980. A review of the Cucurbitaceae. Bot. J. Linnean Soc. 81:233-247.

Johnson, W.C., L.E. Jackson, O. Ochoa, R. Van Wijk, J. Peleman, D.A. St. Clair, and R.W. Michelmore. 2000. Lettuce, a shallow-rooted crop, and Lactuca serriola, its wild progenitor, differ at QTL determining root architecture and deep soil water exploitation. Theor. Appl. Genet. 101:1066-1073

Kempthorne, O. 1969. An introduction to genetic statistics, Iowa State Univ. Press, Ames.

Leskovar, D.I. and P.J. Stoffella. 1995. Vegetable seedling root systems: Morphology, development, and importance. HortScience 30(6): 1153-1159

Lynch, J. 1995. Root architecture and plant productivity. Plant Physiol. 109:7-13.

Mliki, A., J. Staub, S. Zhangyong, and A. Ghorbel. 2001. Genetic diversity in melon (Cucumis melo L.): An evaluation of African germplasm. Genet. Resources Crop Evol. 48:587-597.

Monforte, A.J., J. García-Mas, and P. Arús. 2003. Genetic variability in melon base don microsatellite variation. Plant Breeding 122:1-6.

Nicola, S. 1998. Understanding root systems to improve seedling quality. Hortechnology 8:544-549

Pace, P.F., H.T. Cralle, S.H.M. El-Halawany, J.T. Cothren, and S.A. Senseman. 1999. Drough-induced changes in shoot and root growth of young cotton plants. J. Cotton Sci. 3:183-187.
Price, A.H., A.D. Tomos, and D.S. Virk. 1997. Genetic dissection of root growth in rice (Oryza sativa L.). I. A hydroponic screen. Theor. Appl. Genet. 95:132-142

Siddique, K.H.M., R.K. Belford, and D. Tennant. 1990. Root-shoot ratios of old and modern, tall and semidwarf wheats in a Mediterranean environment. Plant Soil 121:89-98.

Tuberosa, R., S. Salvi, M.C. Sanguineti, M. Maccaferri, M. Giuliani, and P. Landi, 2003. Searching for quantitative trait loci controlling root traits in maize: A critical appraisal. Plant Soil 255:35-54

Wells, C.E. and D.M. Eissenstat. 2003. Beyond the roots of young seedlings: The influence of age and order on fine root physiology. J. Plant Growth Regulat. 21:324-334.

Zheng, B.S., L. Yang, W.P. Zhang, C.Z. Mao, Y.R. Wu, K.K. Yi, F.Y. Liu, and P. Wu. 2003. Mapping QTLs and candidate genes for rice root traits under different water-supply conditions and comparative analysis across three populations. Theor. Appl. Genet. 107:1505-1515

Zhu, J., S.M. Kaeppler, and J. Lynch. 2005. Mapping QTLs for lateral root branching an length in maize (Zea mays L.) under differential phosphorus supply. Theor. Appl. Genet. 111:688-695

Zobel, R.W. 2005a. Primary and secondary root systems, p. 3-14. In: S.F. Wright and R.W.Zobel (eds.). Roots and soil management: Interactions between roots and the soil. Agron. Monograph 48. Amer. Soc. Agron., Crop Sci. Soc. Amer., and Soil Sci. Soc. Amer., Madison, Wis.

Zobel, R.W. 2005b. Tertiary root systems, p. 35-56. In: S.F. Wright and R.W. Zobel (eds.). Roots and soil management: Interactions between roots and the soil. Agron. Monograph 48. Amer. Soc. Agron., Crop Sci. Soc. Amer., and Soil Sci. Soc. Amer., Madison, Wis. 